\title{
Strategi Periklanan Online Shop Garasi Barokah Di Media Sosial Instagram
}

\author{
Jusuf Fadilah \\ Universitas Bina Sarana Informatika \\ jusuf.jff@bsi.ac.id
}

Cara Sitasi: Fadilah, J. (2019). Strategi Periklanan Online Shop Garasi Barokah Di Media Sosial Instagram. Jurnal Komunikasi, 10(1), 19-25.

\begin{abstract}
This study discusses the online shop advertising strategy of Garasi Barokah on social media Instagram. The research method used is qualitative research with the format of field research. The data source in this study consists of two data sets, namely field data and written data. The results showed that the advertising strategy in the diecast manager's perspective, namely the selection of social media Instagram as a means of advertising communication because of the advantages of its social system, namely the Comment and DM features (Direct Message) where the system creates a personal interaction and communication space for business people to exchange messages intensive between traders and traders with buyers. Three aspects in presenting online shop advertising strategies Garasi Barokah on social media Instagram, First, the visual aspect of presenting photos of products is original diecast. Second, the communication aspect, namely the ad text that contains messages about diecast product specifications or specifications, the advantages of diecast products, the price of diecast products, where advertising sentences are made more persuasive which aims to influence consumers. Third, the interactive aspect seeks the service of the purchase or transaction process, contact number and address of the buyer that allows direct interaction between the merchant and the buyer, commonly called Cash On Delivery (COD). The inhibiting factors for the product advertising process are diecast, which is related to incompleteness of identity or found false accounts that are misused by certain individuals. The conclusion of this study recommends that the online shop manager of Garasi Barokah should implement strict rules regarding the identity of buyers (consumers), more effective use of the latest features from Instagram, and implement advertising communication strategies across other social media such as Facebook, Line, Whatsapp and Twitter accounts.
\end{abstract}

Keywords: Advertising Strategy, Garasi Barokah, Instagram

\section{PENDAHULUAN}

Di zaman kehidupan masyarakat modern saat ini menunjukkan kebutuhan informasi yang semakin tinggi seiring dengan kemajuan teknologi informasi dan komunikasi. Peningkatan teknologi informasi dan komunikasi mengakibatkan dunia tidak lagi mengenal batas, jarak, ruang, dan waktu. Seseorang dapat dengan mudah mengakses beragam informasi dan kejadian di belahan dunia lain, tanpa harus berada di tempat tersebut. Padahal dahulu, untuk mencapai tempat itu memakan waktu berjam-jam, tetapi saat ini informasi dapat diakses dalam hitungan detik melalui seperangkat komputer atau mobile phone yang memiliki konektivitas internet.

Internet turut mengubah bentuk masyarakat sebagaimana yang diungkapkan oleh McLuhan bahwa kekuatan internet memungkinkan umat manusia hidup di dalam dunia yang disebutnya sebagai desa global (global village) (Piliang, 2011).
Perkembangan internet memberi banyak pergerseran dalam tatanan kehidupan masyarakat, bahkan dari tahun ke tahun pengguna internet juga mengalami peningkatan di seluruh dunia termasuk Indonesia.

Layanan internet (interconnection networking) sangat beragam dan senantiasa berinovasi sesuai dengan kebutuhan masyarakat, antara lain layanan surat elektronik (email), world wide web (www), ecommerce, e-government, e-banking, jejaring media sosial dan sebagainya. Internet sebagai jaringan media yang tercepat mengalami inovasi ke segala lini serta adaptif dengan kebutuhan masyarakat, sehingga hampir semua media dapat dikoneksikan ke jaringan internet. Pesatnya perkembangan internet juga berdampak dalam pemasaran, khususnya internet marketing sebagai sarana pemasaran kontemporer yang sedang gandrung dibicarakan.

Pada saat ini banyak pelaku bisnis mulai mengembangkan usaha-usaha yang dahulu dikelola 
secara off-line kini mulai kearah online untuk efisiensi biaya sekaligus dalam rangka efektivitas komunikasi periklanan sehingga mempermudah para pelanggan mengakses informasi produk yang ditawarkan. Para pelaku bisnis yang dulu hanya memasarkan produknya melalui toko konvensional, kini mulai beralih menggunakan internet sebagai media pemasaranya. Dari segi bahasa, toko online berasal dari dua suku kata, yakni toko dan online. Secara bahasa tersebut kita dapat mengartikan toko online sebagai tempat terjadinya aktivitas perdangan atau jual beli barang yang terhubung ke dalam suatu jaringan, dalam hal ini jaringan internet. (Yusuf, 2012)

Secara umum terdapat tujuh tempat penjualan secara online, antara lain forum jual beli, jejaring sosial, mailing list, blog, domain, messenger dan komunitas online.

Semakin tingginya pertumbuhan pengguna internet di Indonesia setiap tahunnya, maka layanan belanja secara online juga berpengaruh pada minat belanja. Salah satu medium pemasaran yang banyak digunakan pelaku bisnis dalam memasarkan produknya adalah online shop berbasis media sosial. Pemasaran yang menggunakan media sosial sebagai media periklanan meningkat secara signifikan, sehingga menggeser penggunaan media iklan konvensional seperti radio, televisi atau majalah. Fenomena ini dapat dilihat dari maraknya penggunaan media sosial terutama Facebook dan Instagram sebagai media pemasaran baik itu usaha skala kecil maupun skala besar. Pemasaran melalui Facebook dan Instagram ini memiliki banyak keunggulan karena proses pemasaran dapat dilakukan kapanpun dan dimanapun, berbiaya rendah serta cepat diketahui orang banyak.

Namun demikian, kemungkinan terjadinya berbagai macam penipuan sangat besar karena penyediaan layanan yang gratis dan terbuka untuk umum menjadi kekurangan dari Online Shop. Fenomena tersebut tentu akan berdampak kepada para pengguna Instagram terutama yang akan berbelanja atau memutuskan untuk membeli barang di Online Shop.

Strategi adalah keseluruhan keputusan kondisional tentang tindakan yang akan dijalankan guna mencapai tujuan (Arifin, 1984). Sedangkan pengertian komunikasi secara etimologis berasal dari bahasa latin communication, dan perkataan ini bersumber pada kata communis. Arti communis disini adalah sama, dalam arti kata sama makna, yaitu sama makna mengenai suatu hal. Secara terminologis istilah komunikasi berarti proses penyampaian pesan atau suatu pernyataan oleh seseorang kepada orang lain. (Wiryanto, 2006)

Strategi pada hakikatnya adalah perencanaan dan manajemen untuk mencapai suatu tujuan. Demikian pula strategi komunikasi merupakan paduan dari perencanaan komunikasi dan manajemen untuk mencapai suatu tujuan. Strategi komunikasi baik secara makro maupun mikro memiliki fungsi menyebarluaskan pesan komunikasi yang bersifat informatif, persuasif, dan instruktif secara sistematis kepada sasaran untuk memperoleh hasil yang optimal. (Effendy, 2008)

Komunikasi pemasaran merupakan salah satu aspek yang sangat penting dalam keseluruhan misi pemasaran sebagai penentu suksesnya sebuah pemasaran. Komunikasi pemasaran digunakan oleh hampir seluruh organisasi ataupun perusahaan industri bisnis untuk mempromosikan apa yang mereka tawarkan dan mencapai tujuan finansial dan nonfinansial. Komunikasi pemasaran dapat dipahami dengan menguraikan dua unsur pokoknya, yaitu komunikasi dan pemasaran. Komunikasi adalah proses di mana pemikiran dan pemahaman disampaikan antarindividu, atau antar organisasi dan individu. (Shimp, 2003)

Dalam komunikasi pemasaran terdapat bauran pemasaran yang terdiri dari Empat P (4P) yaitu Product (produk), Price (Harga), Place (Tempat), dan Promotion (promosi).

1. Product (produk)

Produk meliputi kualitas, keistimewaan, desain, gaya, keanekaragaman, bentuk, kemasan, ukuran, pelayanan, jaminan, dan pengambilan.

2. Price (Harga)

Merupakan jumlah uang yang dikeluarkan atau dibayarkan oleh konsumen untuk produk tertentu. Terdapat tiga faktor dalam menentukan harga suatu produk, yaitu meliputi kualitas produk, tingkat persaingan, dan kegiatan promosi.

3. Place (Tempat)

Pendistribusian barang atau produk bagi konsumen yang tepat pada sasaran perusahaan.

4. Promotion (promosi)

Bentuk kegiatan komunikasi guna menciptakan kesadaran dan ketertarikan konsumen terhadap produk. Promosi merupakan salah satu faktor penentu keberhasilan suatu program pemasaran yang bersifat membujuk. (Wijayanti, 2012)

Dengan berkembangnya teknologi, media promosi semakin bertambah salah satunya melalui media sosial Instagram, dengan menggunakan media ini produsen tidak membutuhkan banyak biaya untuk mempromosikan produk, jangkauannya pun lebih luas. Media sosial merupakan sarana bagi konsumen untuk berbagi informasi teks, gambar, audio, dan video dengan satu sama lain dan dengan perusahaan dan sebaliknya. (Kotler, 2007)

Dari definisi tersebut di atas dapat ditarik kesimpulan bahwa dalam penggunaan sosial media 
merupakan sarana pertukaran informasi antar individu dan dapat digunakan juga sebagai sarana promosi/periklanan. Media sosial memiliki beberapa perbeda jenis iklan yang memungkinkan untuk mengambil keuntungan dari fitur unik setia situs. Jenisnya kini terus berkembang, dengan menggunakan sosial media perusahaan dapat menemukan lebih banyak cara efektif untuk mentargetkan penggunanya.

Dalam kaitan ini, peneliti akan menganalisis bagaimana strategi komunikasi periklanan yang dilakukan oleh online shop Garasi Barokah di media sosial Instagram.

\section{METODE PENELITIAN}

Jenis penelitian ini adalah penelitan deskriptif dengan menggunakan metode pendekatan penelitian kualitatif. Penelitian ini termasuk dalam penelitian kualitatif oleh karena data yang digunakan berupa kata-kata dan gambar yang akan dianalisis untuk memeroleh gambaran yang utuh atas permasalahan yang dikaji. Penentuan subjek penelitian dalam penelitian ini menggunakan teknik purposive. Informan penelitian ini sebanyak 10 orang yang terdiri dari pengelola/admin Garasi Barokah dan para pembeli diecast di online shop Garasi Barokah.

Adapun teknik analisis data dalam penelitian ini adalah model interaksi Miles dan Huberman, yakni: 1. Data Reduction (Reduksi Data)

Data yang diperoleh dari lapangan jumlahnya cukup banyak, maka perlu dicatat secara teliti dan rinci. Semakin lama peneliti kelapangan, maka jumlah data akan semakin banyak, kompleks dan rumit. Untuk itu perlu dilakukan analisis data melalui reduksi data. Mereduksi data berarti merangkum, memilih hal-hal yang pokok, menfokuskan pada hal-hal yang penting dicari tema dan polanya. Dengan demikian data yang telah direduksi akan memberikan gambaran yang lebih jelas, dan mempermudah peneliti untuk melakukan pengumpulan data selanjutnya, mencari bila diperlukan.

\section{Data Display (Penyajian Data)}

Setelah data direduksi, maka langkah selanjutnya adalah mendisplaykan data. Dalam penelitian kualitatif, penyajian data bisa dilakukan dalam bentuk uraian singkat, bagan, hubungan antar kategori, flowchart dan sejenisnya. Yang paling sering digunakan untuk menyajikan data dalam penelitian kualitatif adalah dengan teks yang bersifat naratif. Dengan mendisplaykan data, akan memudahkan untuk memahami apa yang terjadi, merencanakan kerja selanjutnya berdasarkan apa yang telah difahami tersebut.

\section{Conclusion Drawing/Verification (Verifikasi)}

Langkah ke tiga dalam analisis data kualitatif adalah penarikan kesimpulan dan verifikasi. Kesimpulan awal yang dikemukakan masih bersifat sementara, dan akan berubah bila tidak ditemukan bukti-bukti kuat yang mendukung pada tahap pengumpulan data berikutnya. Tetapi apabila kesimpulan yang dikemukakan pada tahap awal, didukung oleh bukti-bukti yang valid dan konsisten saat peneliti kembali ke lapangan mengumpulkan data, maka kesimpulan yang dikemukakan merupakan kesimpulan yang kredibel. Kesimpulan dalam penelitian kualitatif dapat menjawab rumusan masalah yang dirumuskan sejak awal, tetapi mungkin juga tidak, karena masalah dan rumusan masalah dalam penelitian kualitatif masih bersifat sementara dan akan berkembang setelah penelitian berada di lapangan. (Sugiyono, 2014)

Pengecekan keabsahan data penelitian ini dilakukan melalui tahap pengecekan kredibilitas data dengan teknik triangulation yaitu mengecek balik derajat kepercayaan suatu informasi yang diperoleh dengan triangulasi sumber, metode dan teori. (Moleong, 2001)

Adapun model trianggulasi yang digunakan adalah memberchek, yaitu proses pengecekan data yang diperoleh peneliti kepada pemberi data. Tujuan memberchek adalah untuk mengetahui seberapa jauh data yang diperoleh sesuai dengan apa yang diberikan oleh pemberi data. Apabila data yang ditemukan disepakati oleh para pemberi data berarti datanya telah valid, sehingga semakin kredibel dan dapat dipercaya, tetapi apabila data yang ditemukan peneliti dengan berbagai penafsirannya tidak disepakati oleh pemberi data maka peneliti perlu melakukan diskusi dengan pemberi data, dan apabila perbedaannya tajam, maka peneliti harus merubah temuannya dan harus menyesuaikan dengan apa yang diberikan oleh pemberi data.

\section{HASIL DAN PEMBAHASAN}

Dari hasil pengamatan diperoleh data bahwa media sosial Instagram pada awalnya digunakan sebagai media komunikasi dan untuk menjalin relasi antarsesama kolektor diecast. Namun seiring perkembangannya, saat ini Instagram juga banyak dimanfaatkan oleh pelaku bisnis; produsen, pewirausaha maupun masyarakat umum sebagai sarana untuk memasarkan diecast dagangannya. Berbagai kelebihan pada media sosial Instagram ini memungkinkan proses bisnis terjadi terutama karena dapat menjangkau konsumen secara massif dan proses komunikasi berjalan dengan cepat. Peluang ini kemudian banyak dimanfaatkan oleh para pelaku bisnis sehingga muncul istilah "Toko Online” atau lazimnya disebut online shop. 
Keberadaan online shop Garasi Barokah di Instagram sangat membantu para anggota untuk menjual ataupun untuk berhubungan langsung dengan calon pembeli (pengguna Instagram) yang sangat potensial dan relatif banyak. Dan juga memudahkan untuk saling berbagi informasi. Para anggota Garasi Barokah dapat mempromosikan berbagai produk diecast customnya ataupun koleksian pribadinya kepada pembeli dengan lebih cepat dan mudah karena Instagram memungkinkan untuk menyampaikan pesan ke semua orang yang telah mengikuti (Following) akun online shop Garasi Barokah.

Berkaitan dengan temuan data observasi dan wawancara, pembahasan mengenai bentuk penerapan strategi komunikasi periklanan pada online shop Garasi Barokah, dapat ditinjau dalam perspektif pengelola (Admin Garasi Barokah) maupun dari sudut pandang para anggota yang mengiklankan diecastnya. Hasil wawancara dengan salah seorang pendiri akun Instagram Garasi Barokah, menyatakan bahwa penerapan strategi komunikasi periklanan melalui media sosial Instagram dianggap efektif karena mayoritas masyarakat Jakarta menggunakan media sosial tersebut.

Karakteristik yang dianggap paling membedakan antara iklan online shop Garasi Barokah dengan iklan di media konvensional (surat kabar, televisi, majalah), adalah aspek bahasa atau teks iklan. Selain menggunakan kalimat yang persuasif, teks iklan online shop Garasi Barokah pada umumnya menggunakan gaya bahasa nonformal seperti bahasa pergaulan sehari-hari.

Berdasarkan keterangan dari pihak anggota online shop Garasi Barokah, menyatakan bahwa penerapan strategi periklanan online shop di media sosial Instagram dianggap efektif. Adapun alasan sehingga strategi komunikasi periklanan online shop di media sosial Instagram dikatakan efektif karena tercapainya keuntungan yang besar. Hal ini terkait dengan terbukanya peluang penjualan diecast dimana target konsumen sangat banyak sesuai jumlah pengakses Instagram khususnya akun Online Shop Garasi Barokah.

Pembahasan Selanjutnya mengenai hambatan komunitas online shop Garasi Barokah dalam menerapkan strategi komunikasi periklanan, informan menyebutkan beberapa hal yang terkait dengan hambatan tersebut. Salah satu hambatan yang dianggap signifikan adalah ketidaklengkapan informasi tentang identitas sebagian pembeli (konsumen) yang pre order ataupun membeli diecast di online shop Garasi Barokah.
Ketidaklengkapan informasi tentang identitas pembeli ini dapat memengaruhi kepercayaan online shop Garasi Barokah bahkan dapat menimbulkan rasa curiga penjual karena khawatir terjadi tindakan penipuan yang dilakukan oleh oknum pembeli. Hal ini sebenarnya telah diantisipasi oleh pengelola akun instagram Garasi Barokah dengan adanya aturan atau sanksi (Blacklist) jika ada pembeli (konsumen) yang melanggar. Namun pengelola akun Instagram online shop Garasi Barokah sulit untuk mendeteksi sedini mungkin siapa saja pembeli (konsumen) yang disinyalir akan melakukan penipuan mengingat banyaknya user Instagram yang terdaftar sebagai pembeli.

Selain itu, ada juga salah satu faktor penghambat lainnya khususnya pembeli (konsumen) yang menggunakan akun palsu yang tidak sesuai identitas asli mereka. Menurut keterangan informan, terkadang pembeli tidak serius untuk melakukan pembelian atau hanya berbasa-basi mengikuti lelang ataupun pre order, lalu kemudian membatalkan secara sepihak kesepakatan mereka dengan penjual. Kasus ini juga sering terjadi, dimana penjual komplain kepada calon pembeli namun pembeli tidak merespon karena menggunakan akun palsu.

Faktor penghambat lainnya juga dikemukakan oleh informan selanjutnya yaitu adanya kendala dalam aspek persaingan bisnis antar sesama penjual diecast. Keterangan yang disebutkan oleh informan menjelaskan bahwa persoalan harga produk diecast menjadi salah satu faktor penghambat karena para penjual diecast terutama yang memiliki barang dagangan yang sama, kadang melakukan persaingan harga yang tidak sehat. Ketentuan harga produk diecast ini menjadi faktor penghambat yang kian terbuka karena pengelola online shop Garasi Barokah juga tidak memberlakukan aturan mengenai harga produk diecast yang sesuai harga pasaran, sehingga penjual dapat semena-mena menentukan harga produknya khususnya diecastdiecast yang sudah dicustom. Kendala ini tidak saja bersumber dari pihak penjual, tetapi menurut informan juga kadang dilakukan oleh konsumen/pembeli.

Berdasarkan uraian pembahasan sebelumnya, dapat disimpulkan beberapa faktor dianggap menghambat proses pemasaran produk diecast online shop Garasi Barokah. Dari aspek pengelola/admin online shop Garasi Barokah belum menerapkan sebuah aturan yang tegas untuk mengatur identitas pembeli (konsumen). Hal ini perlu diterapkan sebagai langkah preventif untuk mencegah terjadinya kasus penipuan, dimana sejak di awal pengelola mengidentifikasi identitas para pembeli (konsumen) di akun Instagram Garasi Barokah. 
Mencermati temuan data yang telah didapatkan oleh peneliti, maka dapat disimpulkan bentuk penerapan strategi periklanan pada online shop Garasi Barokah. Strategi periklanan yang pertama dilihat dalam perspektif pengelola online shop Garasi Barokah, yakni pemilihan medium pemasaran yang dapat menunjang proses periklanan produk. Dalam konteks ini pengelola online shop Garasi Barokah memilih media sosial Instagram sebagai sarana komunikasi periklanan karena kelebihan fitur Instagram yang interaktif (fitur Komentar dan Direct Message) menjadi solusinya untuk konsumen dapat menghubungi langsung penjual untuk bertanya lebih lanjut tentang produk diecast.

Bentuk penerapan strategi periklanan juga dapat dilihat dalam sudut pandang online shop Garasi Barokah. Strategi periklanan yang dimaksud belum sepenuhnya diterapkan oleh online shop Garasi Barokah. Hal ini dimungkinkan terjadi karena keterbatasan pengetahuan para anggota komunitas yang menjadi admin di online shop Garasi Barokah yang mayoritasnya tidak memahami secara teoritis ilmu pemasaran termasuk strategi komunikasi periklanan. Sistem media sosial Instagram juga cenderung memberikan ruang kebebasan bagi para penggunanya sehingga pola periklanan cenderung tidak dirancang sedemikian rupa seperti lazimnya iklan di media surat kabar dan televisi.

Meskipun tanpa didasari sebuah pengetahuan konseptual dan teoritis yang memadai, sebenarnya para admin di akun Instagram Garasi Barokah juga menerapkan strategi komunikasi dalam periklanan. Dalam kaitan ini peneliti menemukan tiga aspek dalam penyajian strategi komunikasi dalam periklanan Garasi Barokah di media sosial Instagram, sebagaimana uraian berikut:

\section{Aspek Visualisasi}

Aspek visual iklan menjadi penentu utama keberhasilan penerapan strategi komunikasi periklanan online shop Garasi Barokah karena khalayak penggunan media sosial tidak melihat secara langsung barang atau produk diecast yang dijual oleh pedagang. Oleh karena itu penyajian secara visual berupa foto diecast harus orisinil dan tidak dimanipulasi agar konsumen percaya dan tertarik untuk membeli diecast tersebut. Beberapa hal yang dilakukan oleh online shop Garasi Barokah pada aspek ini adalah memposting foto produk diecast sesuai kondisinya, yang menunjukkan wujud fisik barang itu baik dalam kondisi baru atau bagus (mint), diecast yang sudah loose dari blisternya, maupun diecast yang sudah dicustom.

\section{Aspek Komunikasi}

Aspek komunikasi yang dimaksud adalah teks atau kalimat iklan yang dikonstruksi oleh online shop
Garasi Barokah. Teks iklan ini memuat berbagai pesan yang dibuat untuk memperjelas keadaan produk diecast yang diposting sehingga pembeli mengetahui kondisi produk diecast tersebut lalu kemudian tertarik untuk membeli. Adapun isi pesan dalam teks iklan tersebut antara lain mengenai judul, type diecast, spesifikasi dan list harga diecast yang disertai gambar dari diecast yang diiklankan.

\section{Aspek Interaktif}

Aspek interaktif yang dimaksud pada model periklanan online shop Garasi Barokah, adalah terbukanya akses bagi pembeli (konsumen) untuk berinteraksi langsung dengan pedagang/penjual, baik melalui layanan fitur komentar dan Direct Message (DM) pada akun instagram Garasi Barokah, maupun interaksi melalui layanan telepon dan pada saat transaksi berlangsung setelah pembeli dan penjual mengadakan kesepakatan untuk bertemu di suatu tempat/Cash On Delivery (COD).

Aspek interaktif ini juga secara nyata dapat dilihat ketika terjadi negosiasi antara penjual dan pembeli di kolom komentar dalam rangka menentukan harga dan tempat bertransaksi (dengan pola Cash On Delivery), kemudian mereka bertemu di suatu tempat yang sudah disepakati agar transaksi lebih aman dan menjamin kepastian transaksi.

Berdasarkan dari uraian tersebut diatas, dapat disimpulkan tiga aspek dalam penyajian strategi komunikasi dalam periklanan online shop Garasi Barokah di media sosial Instagram, Pertama, aspek visual berupa penyajian foto produk diecast secara orisinil. Kedua, aspek komunikasi yaitu teks iklan yang memuat pesan tentang penjelasan atau spesifikasi produk diecast, kelebihan-kelebihan produk diecast, harga produk diecast, dimana kalimat iklan dibuat lebih persuasif yang bertujuan untuk memengaruhi atau membujuk konsumen untuk membeli produk diecast tersebut. Ketiga, aspek interaktif berupaya layanan proses pembelian atau transaksi, nomor kontak serta alamat pembeli yang memungkinkan terjadinya interaksi secara langsung antara pedagang dan pembeli (COD).

Berdasarkan temuan data yang telah diuraikan, juga dapat dilihat adanya proses negosiasi dan transaksi sebagai kelanjutan dari proses komunikasi yang sebelumnya dilakukan oleh online shop Garasi Barokah. Negosiasi dan transaksi itu berlangsung dalam kerangka komunikasi yang melibatkan komunikator (penjual) dan komunikan (pembeli) sehingga terjadi kesepahaman pesan diantara mereka. Hal ini sejalan dengan konsep umum tentang iklan, dijelaskan bahwa "iklan adalah segala bentuk pesan tentang suatu produk yang disampaiakan lewat suatu media dan dilaksanakan 
oleh pemrakarsa yang dikenal serta ditujukan kepada sebagian atau seluruh masyarakat”. (Junaedhie, 1991)

Konsep iklan pada online shop Garasi Barokah juga memuat empat komponen komunikasi periklanan, yaitu:

1. Pemrakarsa, yaitu Admin Pengelola online shop Garasi Barokah

2. Pesan atau teks iklan sebuah produk diecast

3. Media atau Instagram sebagai sarana periklanan

4.Khalayak atau pengguna Instagram sebagai konsumen

Dengan demikian, konsep periklanan pada akun Instagram online shop Garasi Barokah sesuai dengan model komunikasi SMCR yang digagas oleh H.Lasswell yang meliputi; komunikator (source), pesan (message), media (channel), dan kahalayak (receiver). (Cangara, 2012)

Iklan yang dipublikasikan oleh online shop Garasi Barokah menekankan pengertian tentang proses penyampaian pesan komunikasi yang terkait dengan sebuah produk diecast dagangan, yang melibatkan komunikator atau Admin Pengelola online shop Garasi Barokah melalui saluran komunikasi (media sosial) untuk disampaikan kepada konsumen atau khalayak pengguna Instagram.

\section{KESIMPULAN}

\section{Kesimpulan}

Berdasarkan hasil penelitian yang dipaparkan sebelumnya, dapat dijelaskan kesimpulan penelitian ini sebagai berikut:

1. Strategi periklanan dalam perspektif pengelola online shop Garasi Barokah, yakni pemilihan media sosial Instagram sebagai sarana komunikasi periklanan karena kelebihan sistem sosialnya yaitu fitur komentar dan Direct Message (DM) dimana sistem ini menciptakan ruang interaksi dan komunikasi bagi para pelaku bisnis sehingga terjadi pertukaran pesan yang intesif antarpedagang maupun pedagang dengan pembeli dalam satu akun. Tiga aspek dalam penyajian strategi periklanan Garasi Barokah di media sosial Instagram, Pertama, aspek visual berupa penyajian foto produk diecast secara orisinil. Kedua, aspek komunikasi yaitu teks iklan yang memuat pesan tentang penjelasan atau spesifikasi produk diecast, kelebihan-kelebihan produk diecast, harga produk diecast, dimana kalimat iklan dibuat lebih persuasif yang bertujuan untuk memengaruhi konsumen untuk membeli produk diecast tersebut. Ketiga, aspek interaktif berupaya layanan proses pembelian atau transaksi, nomor kontak serta alamat pembeli yang memungkinkan terjadinya interaksi secara langsung antara pedagang dan pembeli (COD).

2. Faktor penghambat proses periklanan produk online shop Garasi Barokah, yaitu dari sisi pengelola belum menerapkan sebuah aturan yang tegas untuk mengatur identitas pembeli (konsumen). Dari sisi pembeli juga ditemukan faktor penghambat yang terkait dengan ketidaklengkapan identitas atau ditemukan adanya akun palsu yang disalahgunakan oleh oknum tertentu yang mengakibatkan terjadinya beberapa kasus penipuan.

\section{Saran}

Berdasarkan kesimpulan tersebut, peneliti merekomendasikan beberapa aspek penting terkait saran dari hasil analisis penelitian. Pertama, merekomendasikan agar pihak pengelola online shop Garasi Barokah sebaiknya menerapkan aturan yang ketat mengenai identitas pembeli (konsumen), lebih mengefektifkan pemanfaatan fitur terbaru di Instagram, dan menerapkan strategi periklanan lintas media sosial, seperti media sosial lainnya yaitu akun Facebook, Line, Whatsapp, Twitter. Kedua, hasil penelitian ini diharapkan ditindaklanjuti oleh akademisi lainnya dengan lebih memperdalam kajian pada aspek komunikasi dan periklanan pada online shop pada media sosial lainnya.

\section{REFERENSI}

Arifin, A. (1984). Strategi Komunikasi; Sebuah Pengantar Ringkas (Cet.III). Bandung: Armico.

Cangara, H. (2012). Pengantar Ilmu Komunikasi (Cet.XIII). Jakarta: Rajawali Press.

Effendy, O. U. (2008). Dinamika Komunikasi (Cet.VII). Bandung: Rosdakarya.

Junaedhie, K. (1991). Ensklopedi Pers Indonesia. Jakarta: PT. Gramedia.

Kotler, P. dan K. L. K. (2007). Manajemen Pemasaran (Jilid 12). Jakarta: PT. Indeks.

Moleong, L. J. (2001). Metodologi Penelitian Kualitatif. Bandung: Rosdakarya.

Piliang, Y. A. (2011). Dunia Yang Dilipat: Tamasya Melampaui Batas-Batas Kebudayaan. Bandung: Matahari.

Shimp, T. A. (2003). Periklanan Promosi \& Aspek Tambahan Komunikasi Pemasaran Terpadu Jilid I (Edisi 5). Jakarta: Erlangga.

Sugiyono. (2014). Metode Penelitian Kuantitatif Kualitatif dan R\&D. Bandung: Alfabeta.

Wijayanti, T. (2012). Marketing Plan! Dalam Bisnis (2nd Editio). Jakarta: PT. Elex Media Komputindo.

Wiryanto. (2006). Pengantar Ilmu Komunikasi (Cet.III). Jakarta: Grasindo.

Yusuf, M. dan A. Y. (2012). 1 Jam Membuat Toko Online dengan Joomla-Virtuemart. 
Yogyakarta: Expert.

\section{PROFIL PENULIS :}

Jusuf Fadilah aktif sebagai Akademisi di Universitas Bina Sarana Informatika sebagai dosen teori dan juga instruktur labolatorium di Fakultas Komunikasi dan Bahasa Universitas Bina Sarana Informatika.

Kritik dan saran sangat diharapkan guna peningkatan kualitas dan penulisan selanjutnya. 